\section{1. 脳卒中リハビリテーションの常識と最先端知識}

産業医科大学リハビリテーション医学 蜂須賀研二

脳卒中リハビリテーションの常識として, 廃用症候群の予 防と治療を紹介する。廃用症候群は身体活動の減少により生 じる病態の総称であり, 最も多い症状は筋力低下, 体力低下, 骨粗鬆症などである，廃用症候群は，病院内では脳卒中発症 急性期から亜急性期にかけて過度のベッド上安静を指示する ことで生じ，自宅では慢性期に非活動的なライフスタイルを とることにより生じる. 対策として, 病院内では早期離床, 抗重力筋の筋活動を伴う訓練, 十分な訓練量, 自宅では日常 生活活動の自立，適度な散歩などが重要である，最新知識と して，歩行支援ロボットを用いた歩行訓練を紹介する。この 装置は体幹を支持し，両側の大腿，下腿・足部をそれぞれ口 ボット・アームで制御し，トレッドミル上を歩行できるよう にする，重度の歩行障害患者の訓練装置として有用であり， 臨床デー夕を提示する。

\section{2. 脳卒中治療の最先端知識}

東京女子医科大学神経内科

内山真一郎

急性虚血性脳卒中には抗血栓療法の適応があり, 血栓溶解 療法, 抗凝固療法, 抗血小板療法が行われているが, 血栓溶 解療法は出血のリスクがあり, 抗凝固療法は有効であるとの エビデンスにそしく, 抗血小板療法の効果はわずかであるこ とから, 新規抗血栓薬や超音波との併用療法が期待されてい る。虚血性脳卒中の再発予防に関しては, 非心原性脳卒中に は抗血小板療法, 心原性脳卒中には抗凝固療法が有効である とのエビデンスが確立されており，ガイドラインでも推奨さ れているが，それらの効果や普及には多くの問題点が残され ている，最近は異なった抗血小板薬の併用療法を検討する大 規模臨床試験が盛んに行われており，心房細動患者において 経ロトロンビン阻害薬の臨床試験も行われた。 さらに, 分子 標的のコンセプトにより多くの新規抗血栓薬が開発され，臨 床応用が模索されている.

\section{3. 生活習慣病と脳卒中予防}

\section{広島大学脳神経内科 松本 昌泰}

人口構造の高路化の進行とともに脳血管障害の罹病者が激 増しつつあり, 寝たきり状態や脳血管性痴呆への進行を抑制 するためにもその発症や再発予防対策の充実が欠かせない. その際に最も参考になるのが脳卒中予防に関する各種の大規 模臨床試験の結果やガイドラインである。しかしながら，治 療ガイドラインを個々の患者に適応する場合には, 各臨床試 験が対象とした患者の危険因子などのプロフィールを十分に 熟知しておく必要がある，また，予防的治療に際しては，医 療経済学的評価に際しても重要な NNT などの基本的用語に 関する知識が欠かせない，演者は本格的な大規模臨床試験で ある PROGRESS 試験に参加することにより, 大規模臨床試 験結果を解釈する上で留意するべき多くの点を学ぶことがで きた. 本講演では, 脳卒中の発症や再発防止を目的として実 施された最近の大規模臨床試験結果につき紹介し，危険因子 の状態に応じて生活習慣の改善を徹底しながら, 抗血栓薬, 降圧薬, 抗高脂血症薬などによる薬物治療を実施する意義に つき解説を試みる。 